\title{
Involvement of Neuronal Nitric Oxide Synthase in Ongoing Fetal Brain Injury following Near-Term Rabbit Hypoxia-Ischemia
}

\author{
Suma Rao ${ }^{a}$ Zhenlang Lin $^{d} \quad$ Alexander Drobyshevsky ${ }^{b}$ Lina Chen ${ }^{\mathrm{e}}$ Xinhai Ji $^{\mathrm{b}}$ \\ Haitao Jic Yirong Yang ${ }^{b}$ Lei Yu ${ }^{b}$ Matthew Derrick ${ }^{a, b}$ Richard B. Silverman ${ }^{c}$ \\ Sidhartha Tan ${ }^{b}$ \\ a Department of Pediatrics, Northwestern University, Chicago, Ill., and ${ }^{b}$ Department of Pediatrics, NorthShore \\ University Healthsystem, and ${ }^{\mathrm{C}}$ Department of Chemistry, Northwestern University, Evanston, III., USA; ${ }^{\mathrm{d}}$ Department of \\ Pediatrics, Wenzhou Medical College, Wenzhou, and e Department of Pediatrics, Sichuan University, Chengdu, China
}

\section{Key Words}

Neuronal nitric oxide synthase - Brain slice model •

Hypoxia-ischemia, in utero - Neuronal nitric oxide synthase inhibitor

\section{Abstract \\ Neuronal nitric oxide synthase (nNOS) and nitric oxide (NO) are implicated in neuronal injury following acute hypoxia- ischemia (HI). Our hypothesis was that NO from nNOS is re- sponsible for ongoing mitochondrial dysfunction in near- term fetal HI. Recently, we synthesized new selective nNOS inhibitors that prevent the cerebral palsy phenotype in our animal model. We tested the efficacy of a selective nNOS in- hibitor (J-8) in fetal brains after in utero $\mathrm{HI}$ in our rabbit mod- el. Brain slices at 29 days gestation were obtained after in utero $\mathrm{HI}$, and immediately cultured in medium containing $\mathrm{JI}-8$ or saline for 3-6 days. Mitochondrial membrane integ- rity and function were determined by flow cytometry using rhodamine 123 and JC-1, and cell death by using propidium iodide. Jl-8 decreased NO production in brain slices and also showed significant preservation of mitochondrial function at both 3 and 6 days $(p<0.05)$ when compared with saline}

and inducible NOS inhibitor 1400W. There was no difference in cell death. In conclusion, nNOS is involved in ongoing mitochondrial dysfunction after in utero $\mathrm{HI}$. The subacute brain slice model could be a tool for studying the mechanisms involved in ongoing neuronal injury, and for rapidly assessing potential neuroprotectants.

Copyright $\odot 2011$ S. Karger AG, Base

\section{Introduction}

Perinatal hypoxic-ischemic brain injury is a significant risk factor for neonatal morbidity and even mortality [1-3]. Injury from hypoxia-ischemia (HI) can result in long-term neurologic consequences such as cerebral palsy, cognitive delays and learning disabilities in both preterm and term infants. Advances in neonatal medicine have led to improved survival of preterm neonates, but the incidence of cerebral palsy has not been substantially reduced $[4,5]$. Except for hypothermia $[6,7]$, there is a paucity of postnatal interventions that offer neuroprotection [8].

\section{KARGER}

(๑) 2011 S. Karger AG, Basel

Fax +4161306 1234

E-Mail karger@karger.ch

www.karger.com
Accessible online at: www.karger.com/dne
Sidhartha Tan, MD

Department of Pediatrics

2650 Ridge Avenue

Evanston, IL 60201 (USA)

Tel. +1 847570 2033, E-Mail sidtan@ uchicago.edu 
Nitric Oxide and Brain Injury

Global HI results in activation of several cellular pathways that ultimately result in brain injury $[1,9]$, including those involving nitric oxide (NO), an important gaseous signaling molecule in the brain [10-12]. NO easily diffuses within the cell and across cell membranes [13]. NO is produced from the amino acid L-arginine by NO synthases. Animal studies have shown that neuronal NO synthase (nNOS) is the abundant isoform found in the brain, especially the cortex, hippocampus, olfactory bulb and amygdala [13-17], and is responsible for production of NO that can have neurotoxic effects [14]. It has been proposed that $\mathrm{NO}$ produces toxic effects by several different mechanisms such as through the $\mathrm{N}$-methyl-D-aspartic acid pathway [14]. Another mechanism is the interaction with superoxide to generate reactive nitrogen species. NO combines with superoxide to form peroxynitrite, which causes nitration of proteins and damage to cellular components, eventually leading to cell death $[18,19]$. Various animal studies have shown that nNOS inhibition may offer protection against injury [20,21], and nNOS knockout mice are protected from HI injury [22]. Most of the data to date have been obtained from studies of rat and mouse brains in cell culture or organotypic slices subjected to acute HI injury. There is a lack of substantial data regarding the cellular mechanisms that are involved in ongoing injury after an HI event in utero. Also, there is evidence from animal studies that neuronal cell death and damage occur for several hours or even days after the acute HI event [1]; these can lead to long-term motor, cognitive and learning disabilities. We therefore set out to study the involvement of $\mathrm{NO}$ and cell injury several days after in utero $\mathrm{HI}$ injury by using a novel nNOS inhibitor in a subacute brain slice model. This could have tremendous clinical therapeutic benefits.

Our laboratory has established a rabbit model of global $\mathrm{HI}$ in utero that results in a cerebral palsy phenotype $[15,18,23]$. This clinically relevant animal model can be used to test key questions about molecular mechanisms involved in HI brain injury. Prior preliminary RT-PCR studies in our laboratory have shown that there is a significant increase in nNOS expression in fetal rabbits after $\mathrm{HI}$ compared with control animals. An increase in NO production has been shown in fetal rabbit brains following acute HI [18].

Recently, new specific nNOS inhibitors have become available. Using a novel fragment hopping approach that effectively utilizes a 1-residue difference in the nNOS active site relative to the other isoforms endothelial (e)NOS and inducible (i)NOS, new bioavailable inhibitors have been synthesized [24]. These inhibitors exhibit a low nanomolar potency for nNOS and 1,000- to 2,000-fold selectivity for nNOS over eNOS. We have recently published a study showing that administration of new nNOS inhibitors prevents the cerebral palsy phenotype in newborn rabbits in our animal model [25], and we have shown a benefit even in mild motor deficits [26]. In this study, we investigated the role of nNOS in ongoing brain injury, utilizing a unique method of obtaining slices from fetal rabbit brains after they have suffered in utero HI. The brain slices are observed ex vivo for 6 days after HI. This enables us to assess the extent and possible mechanisms of ongoing neuronal injury in the subacute phase. It also provides an opportunity to study the crucial time period when exogenous neuroprotectants can be administered to limit the extent of the injury, as well as a quick model to test several potential neuroprotectants.

\section{Materials and Methods}

The study was approved by the animal review committee of the Evanston Northwestern Healthcare Research Institute. All animals received humane care in compliance with the National Institutes of Health 'Guide for the care and use of laboratory animals’ (publication No. 85-23, rev. 1985).

\section{$n$ NOS Inhibitor JI-8}

JI- 8 is a new designer drug that was created using a novel fragment hopping approach [24]. The chemical structure of JI-8 is cis$\mathrm{N}^{1}$-[4'-6"'-amino-(4' -methylpyridin-2"'-ylmethyl)pyrrolidin-3'yl]-N²-[2'-(3"'-fluorophenyl)ethyl]ethane-1,2-diamine. The high selectivity of JI-8 for nNOS can be seen in its dissociation constant $\left(\mathrm{K}_{\mathrm{i}}\right)$ of $0.014 \mu \mathrm{M}$ for $\mathrm{nNOS}, 27.95 \mu \mathrm{M}$ for eNOS, and $4.06 \mu \mathrm{M}$ for iNOS $[25,27]$.

\section{Surgical Procedure}

Timed pregnant New Zealand white rabbits (Myrtle's Rabbits, Thompson Station, Tenn., USA) at 29 days of gestation ( $92 \%$ term) were used. The dams were anesthetized with intravenous fentanyl $75 \mu \mathrm{g} / \mathrm{kg} / \mathrm{h}$ and droperidol $3.75 \mathrm{mg} / \mathrm{kg} / \mathrm{h}$, and bag-and-mask ventilation was provided to maintain normal arterial $\mathrm{pH}$ (7.357.45), $\mathrm{PCO}_{2}(32-45 \mathrm{~mm} \mathrm{Hg})$ and $\mathrm{PO}_{2}(70-100 \mathrm{~mm} \mathrm{Hg})$. The dams then underwent spinal anesthesia by administration of $0.75 \%$ bupivacaine through a 25 -gauge spinal needle in the L2-L5 intervertebral space. The fentanyl and droperidol were reduced by one fifth to allow the dam to breathe spontaneously through a mask. Uterine ischemia was induced by inserting a 4-Fr Fogarty arterial embolectomy catheter (Baxter Healthcare Corporation, Santa Ana, Calif., USA) into the left femoral artery, advancing it 10 $\mathrm{cm}$ into the descending aorta to above the uterine and below the renal arteries, and inflating the balloon with $300 \mu \mathrm{l}$ of saline to induce HI. Blood pressure monitoring of the right leg using Doppler sonography was performed to ensure continued ischemia. 


\section{MRI Determination of Time of HI}

Two dams were put in a 3 -tesla clinical magnet and subjected to uterine ischemia, as described before [28]. Using a quadrature extremity coil, single-shot fast spin echo $\mathrm{T}_{2}$-weighted images were obtained with 25-32 axial slices of $4 \mathrm{~mm}$ thickness, a matrix of $256 \times 192$, and a field of view of $16 \mathrm{~cm}$. Diffusion-weighted echoplanar images with $b=0$ and $0.8 \mathrm{~ms} / \mu^{2}$, TR/TE $=7,400 / 70 \mathrm{~ms}$, 2 averages, were continuously obtained, with each acquisition taking $2 \mathrm{~min}$. Apparent diffusion coefficients (ADC) of fetal brains were then determined as before [28]. The time of uterine ischemia for embryonic day (E) 29 fetuses in this study (fig. 1) was determined from the time it took to reach the ADC at E25 gestation, which had identified hypertonic kits in the previous study [28]. This time was determined to be $30 \mathrm{~min}$. After $30 \mathrm{~min}$ of ischemia, the fetuses were removed by hysterotomy, and the brains were placed in dissection medium (Gey's Balanced Salt Solution, $50 \% \mathrm{D}$-glucose and $3 \mathrm{M} \mathrm{KCl}$ ).

\section{Preparation of Brain Slices}

$400-\mu \mathrm{m}$ slices of whole brain, parietal cortex and hippocampus were obtained using a Vibratome (Vibratome Company, St. Louis, Mo., USA). To control for variability between fetuses, individual slices from a single fetus were divided into left and right sides and randomly assigned to be placed on cell culture inserts (Millipore Corporation, Billerica, Mass., USA) in 6-well tissue culture plates. The plates contained dissection medium with either saline (controls) or JI- 8 or $1400 \mathrm{~W}$, an iNOS inhibitor (fig. 2b). A concentration of $25 \times \mathrm{K}_{\mathrm{i}}$ was used, 0.35 and $0.25 \mu \mathrm{M}$ for JI- 8 and $1400 \mathrm{~W}$, respectively. Left and right sides of a slice from one animal were treated in contiguous pairs with either saline and JI8 , saline and $1400 \mathrm{~W}$, or JI-8 and $1400 \mathrm{~W}$. After incubation at $4{ }^{\circ} \mathrm{C}$ for $1 \mathrm{~h}$, the medium was changed to Opti-MEM (Hank's Balanced Salt Solution, Horse Serum, Opti-MEM from Invitrogen) supplemented with either saline, JI- 8 or $1400 \mathrm{~W}$ at the same concentrations. The slices were then incubated at $37^{\circ} \mathrm{C}$ with $5 \% \mathrm{CO}_{2}$ for $72 \mathrm{~h}$. Flow cytometry was run on half the number of brain slices. The culture medium, Neurobasal medium (Life Technologies) with saline, JI- 8 or $1400 \mathrm{~W}$ was replenished for the remainder of the slices and incubated at $37^{\circ} \mathrm{C}$ with $5 \% \mathrm{CO}_{2}$ for $144 \mathrm{~h}$.

\section{Fluorescent Staining}

During the first phase of our experiments, the brain slices were stained with fluorescent probes to determine the viability of the slices. Fluorescent staining was done at 2 time points after obtaining the brain slices: after $1 \mathrm{~h}$ of culture and 3 days of culture ex vivo. BCECF $\left[\left(2^{\prime}, 7^{\prime}\right.\right.$-bis-2-carboxyethyl)-5-(and-6)carboxyfluorescein] was used to stain live neuronal cells, and propidium iodide (PI) was used to stain dead cells. The slices were then examined under the fluorescent microscope.

\section{Brain Cell Suspension}

After 3 days of incubation, half the number of brain slices were placed in $0.025 \%$ trypsin and incubated in a rotating shaker at $37^{\circ} \mathrm{C}$ for $45 \mathrm{~min}$. Based on our previous studies, this concentration of trypsin was determined to be the lowest concentration of trypsin that would enable dissociation of cells without causing significant cell death [23]. The brain suspension was spun at $650 \mathrm{~g}$ for $10 \mathrm{~min}$ at $4^{\circ} \mathrm{C}$, washed with Hank's Balanced Salt Solution before limited titration (20 times) in Neurobasal medium (Life Technologies). The brain suspension was passed

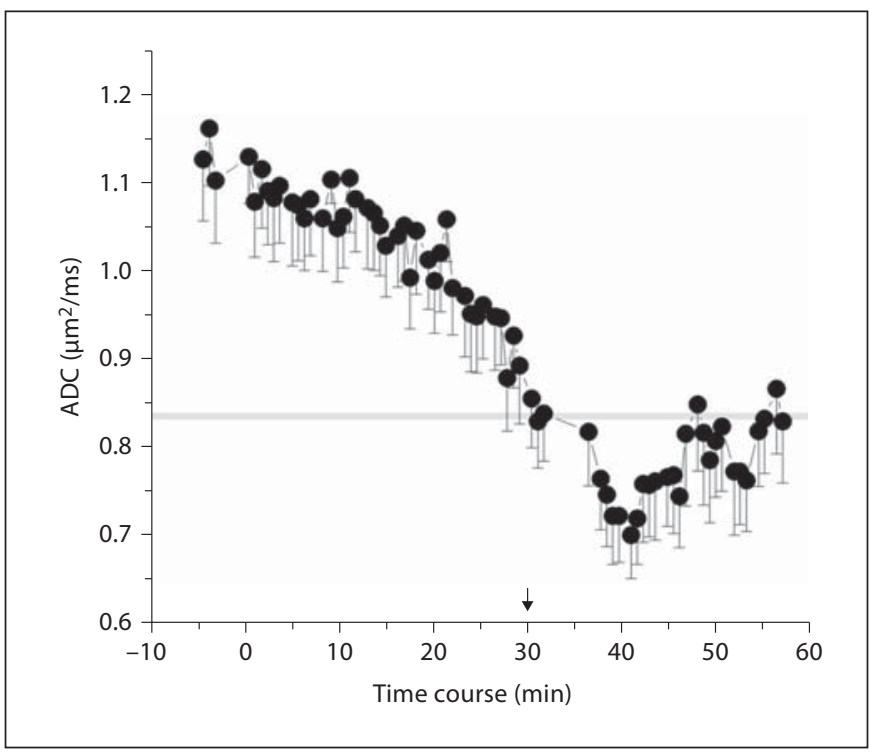

Fig. 1. ADC of fetal brains obtained from diffusion-weighted imaging on 12 fetuses ( $\mathrm{n}=2 \mathrm{dams}$ ), showing the time course at E29 following uterine ischemia (0-40 min). Means \pm SEM. Line at 0.83: previously published threshold for E25 fetuses that are destined to be hypertonic [28].

through a sterile $70-\mu \mathrm{m}$ filter to produce a single-cell suspension [23]. The culture medium was replenished for the remainder of the slices and incubated at $37^{\circ} \mathrm{C}$ with $5 \% \mathrm{CO}_{2}$ for $144 \mathrm{~h}$. The procedure of brain cell suspension was repeated on these slices. Flow cytometric assessment was done on the single-cell suspensions.

\section{Flow Cytometry Assessment}

The flow cytometer (FACSCalibur; Becton, Dickinson \& Co., San Jose, Calif., USA) was used to assess cellular processes in slices after 72 and $144 \mathrm{~h}$ of incubation. The single-cell suspensions obtained from slices were incubated with rhodamine 123 (Calbiochem, San Diego, Calif., USA) or JC-1 (5,5',6,6'-tetrachloro$1,1^{\prime}, 3,3^{\prime}$-tetraethylbenzimidazolocarbocyanine iodide; Molecular probes). For rhodamine $123,5 \mu \mathrm{g}$ was added to $300 \mu \mathrm{l}$ of cell suspension and incubated at $37^{\circ} \mathrm{C}$ for $5 \mathrm{~min}$. Rhodamine-positive cells were defined as $>10^{1}$ fluorescence units (fig. $3 \mathrm{a}$ ). For the mitochondrial membrane potential-sensitive JC-1, $5 \mu \mathrm{l}$ of a $1 \mathrm{mg} / \mathrm{ml}$ stock was added to $300 \mu \mathrm{l}$ sample and incubated for $30 \mathrm{~min}$ at $37^{\circ} \mathrm{C}$ and then analyzed on the flow cytometer. JC-1 fluorescencepositive cells were selected that had more red than green and $>10^{2}$ fluorescence units (fig. 3b). Cell death was assessed using PI, 10 $\mu \mathrm{l}$ of a $1 \mathrm{mg} / \mathrm{ml}$ stock, added to $300 \mu \mathrm{l}$ sample immediately prior to assessment by flow cytometry. The advantage of using a flow cytometer lies in its ability to rapidly assess a large number of cells and to provide a nonbiased quantification [29]. Our laboratory has shown that the procedure of preparing a cell suspension does not inflict significant injury to cells [23].

Another aliquot of cells was fixed in $4 \%$ paraformaldehyde at $37^{\circ} \mathrm{C}$ for $10 \mathrm{~min}$ and chilled on ice. They were permeabilized in 

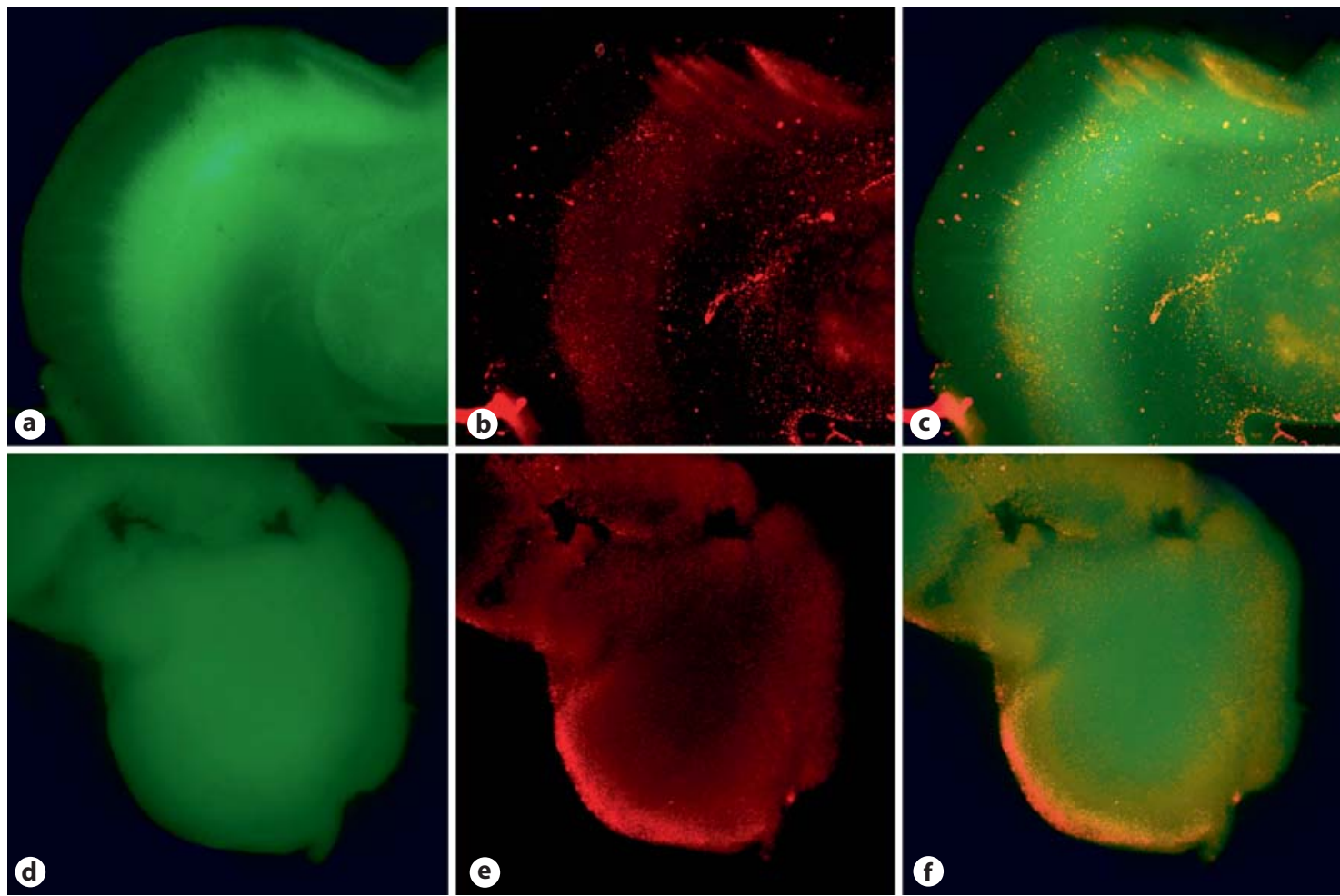

Fig. 2. Fluorescent microscopic pictures of brain slices obtained from a rabbit fetus after in utero HI staining with BCECF (a, d) and propidium iodide $(\mathbf{b}, \mathbf{e})$ at $1 \mathrm{~h}(\mathbf{a}-\mathbf{c})$ and $72 \mathrm{~h}(\mathbf{d}-\mathbf{f}) . \mathbf{c}, \mathbf{f}$ Superimposed images of $\mathbf{a}$ and $\mathbf{b}$ or $\mathbf{d}$ and $\mathbf{e}$, respectively. The majority of the slice was still viable at the end of $72 \mathrm{~h}$.

$0.1 \%$ Triton $\mathrm{X}-100$ in $1 \times \mathrm{PBS}$ at room temperature for $10 \mathrm{~min}$ and washed twice with incubation buffer (0.5\% BSA in PBS). An aliquot of $10^{6}$ cells was blocked in $1 \mathrm{ml}$ incubation buffer at room temperature for $10 \mathrm{~min}$. Primary antibodies used were goat antinNOS (GenWay; catalog No. 18-783-78599) with normal goat IgG as isotype control (Santa Cruz Biotechnology; catalog No. sc-2028), and mouse anti-NeuN (Chemicon; catalog No. MAB377) with normal mouse IgG as isotype control (Santa Cruz Biotechnology; catalog No. sc-2025). The primary antibodies were added at a concentration of 1:100, and the solution was incubated at room temperature for $1 \mathrm{~h}$. Cells were then washed with incubation buffer and centrifuged twice at $650 \mathrm{~g}$ for $5 \mathrm{~min}$ to remove supernatant. The cells were resuspended in $1 \mathrm{ml}$ incubation buffer, and 1:1,000 secondary antibody was added and incubated for $30 \mathrm{~min}$. To detect mouse primary antibody, we used rabbit anti-mouse conjugated with Alexa 647 (Invitrogen; A21239); for goat primary antibody, we used donkey antigoat conjugated with FITC (Santa Cruz Biotechnology; catalog No. sc-2024). The cells were then washed twice as before. Finally, the cells were resuspended in $500 \mu \mathrm{l}$ of PBS and checked with a BD Aria II flow cytometer. The isotype control samples were used to set the negative gate. Out of the cells that were FITC(nNOS) positive, the percentage of Alexa 647-positive cells (APC or allophycocyanin channel) was determined to detect NeuNpositive cells.

\section{Measurement of NO Production}

Measuring NO production in neurons by the formation of nitrate and nitrite $\left(\mathrm{NO}_{\mathrm{x}}\right)$ was done using the $\mathrm{NO}$ analyzer (Sievers, Boulder, Colo., USA). Brain slices from control fetuses and those treated with JI-8 were homogenized and the $\mathrm{NO}_{\mathrm{x}}$ level determined.

\section{Gender Determination}

The gender of the rabbit fetuses was determined by using a PCR technique. We obtained samples of DNA isolated from pieces of liver tissue to detect SRY. About $200 \mathrm{ng}$ DNA were used for PCR. Amplification of SRY fragments was done in 30 cycles under the following conditions: denaturation steps of $94^{\circ} \mathrm{C}$ for $2 \mathrm{~min}$, $94^{\circ} \mathrm{C}$ for $20 \mathrm{~s}, 64^{\circ} \mathrm{C}$ for $30 \mathrm{~s}, 72^{\circ} \mathrm{C}$ for $30 \mathrm{~s}$, and $72^{\circ} \mathrm{C}$ for $10 \mathrm{~min}$, using the specific primers OcSRY21F: $5^{\prime}$-AGC GGC CAG GAA CGG GTC AAG and OcSRY23R: 5'-CCT TCC GGC GAG GTC TGTACT TG. The PCR products obtained were analyzed by electrophoresis in 3\% agarose gel containing SYBR Green, and visualized by the UVP BioDoc-It system.

\section{Statistical Analysis}

The data were analyzed using a paired t test. The $\alpha$-error was set at $<0.05$. All analyses were done with SAS version 9.1 for Windows. 


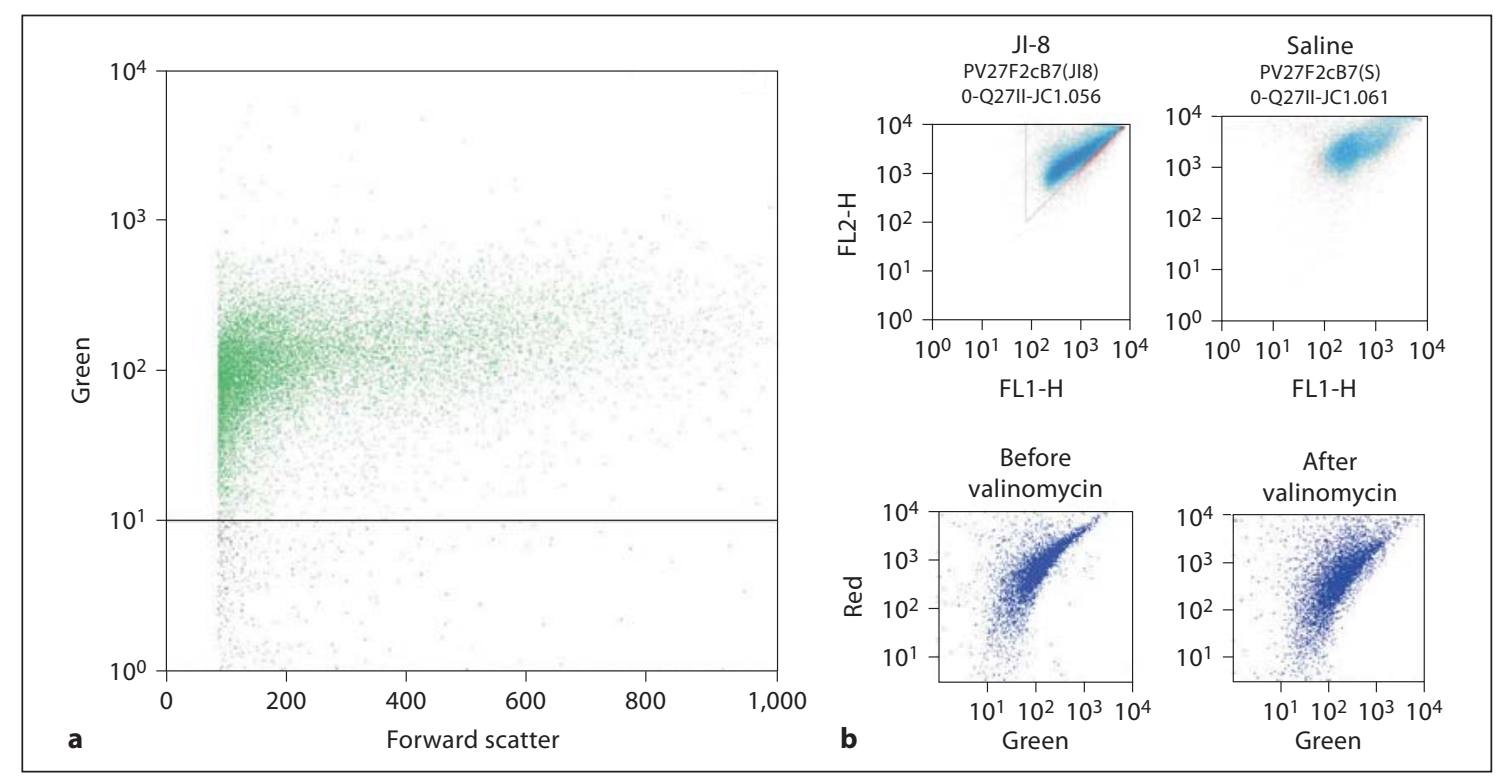

Fig. 3. Data from a hypoxia slice and representative flow cytometry plots for the 2 mitochondrial membrane-sensitive dyes rhodamine 123 (a) and JC-1 (b). Rhodamine-positive cells were defined as $>10^{1}$ fluorescence units (FU). JC-1 stains red at high concentrations and green at low concentrations. Active uptake by mitochondria concentrates JC-1. Cells were defined as positive if there were $>10^{2}$ red $\mathrm{FU}$ and $>10^{2}$ green $\mathrm{FU}$ and there were more red FU than green FU (triangle depicts $\mathrm{R}>\mathrm{G}$ ). Two halves

\section{Results}

\section{Determining Equipotent Time of Uterine Ischemia at E29 Gestation}

The time course of ADC shows that at approximately 30 min, the mean ADC reached was equal to the threshold ADC at E25 gestation that predicted hypertonic kits postnatally (fig. 1). Uterine ischemia longer than $30 \mathrm{~min}$ resulted in increased numbers of perinatal deaths (data not shown).

\section{Fluorescent Staining Showing Viable Slices}

Fluorescent microscopic studies of the slices after fluorescent staining using BCECF for the live cells and PI for the dead cells indicated that the majority of the brain slice is viable even after $72 \mathrm{~h}$ (fig. 2). This indicates that the subacute brain slice model can be used for further analysis of effects of nNOS inhibitors and also for flow cytometry.

\section{JI-8 Reduces NO Production}

The level of $\mathrm{NO}_{\mathrm{x}}$ in brain slices was used in order to confirm that JI-8 did in fact reduce the amount of NO produced (fig. 4). $\mathrm{NO}_{\mathrm{x}}$ production was significantly lower from the same brain slice were treated with JI-8 or saline. The upper left panel shows the data from the half-slice treated with JI-8, and the upper right panel shows the other half-slice treated with saline. Note the larger number of cells R $>$ G with JI-8 treatment now seen as a deeper blue color. Valinomycin administration that causes a loss of mitochondrial membrane potential decreases the red fluorescence without affecting green (lower panels).

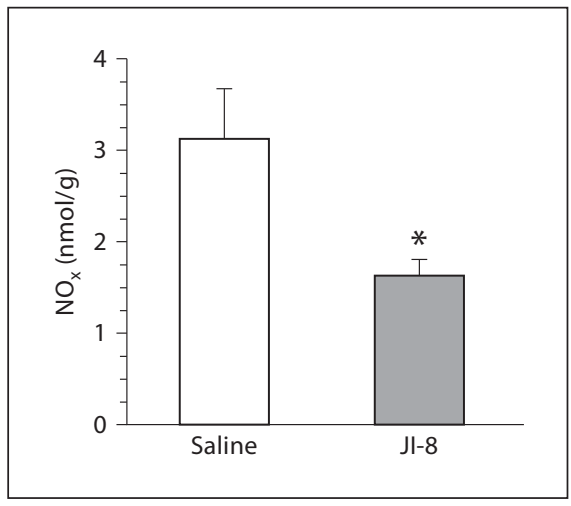

Fig. 4. Significant reduction in $\mathrm{NO}_{\mathrm{x}}$ production (in nanomoles per gram of brain tissue) at $72 \mathrm{~h}$ in brain slices treated with the nNOS inhibitor JI-8 compared with saline (control) in HI fetuses. ${ }^{*} \mathrm{p}<$ 0.05 .

in the JI-8-treated group. This indicates that the novel drug JI- 8 reduces the production of NO by selectively inhibiting NOS in the brain. This drug can therefore be used to study whether NO is involved in continuing injury to cells several hours after HI injury. 
Table 1. Rhodamine 123 flow cytometry assessment in control and hypoxia slices

\begin{tabular}{|c|c|c|c|c|c|c|c|c|c|c|c|}
\hline $\begin{array}{l}\text { Cells } \\
\text { Rh +ve }\end{array}$ & $\begin{array}{l}\text { Age } \\
\text { days }\end{array}$ & saline & JI-8 & saline & $1400 \mathrm{~W}$ & $\begin{array}{l}\text { saline } \\
\text { male }\end{array}$ & $\begin{array}{l}\mathrm{JI}-8 \\
\text { male }\end{array}$ & $\begin{array}{l}\text { 1400W } \\
\text { male }\end{array}$ & $\begin{array}{l}\text { saline } \\
\text { female }\end{array}$ & $\begin{array}{l}\text { nNOS } \\
\text { JI-8 } \\
\text { female }\end{array}$ & $\begin{array}{l}\text { iNOS } \\
1400 \mathrm{~W} \\
\text { female }\end{array}$ \\
\hline Whole brain & 3 & $\begin{array}{l}50 \pm 6 \\
n=32\end{array}$ & $\begin{array}{l}43 \pm 5 \\
n=32\end{array}$ & & & & & & & & \\
\hline Whole brain & 6 & & & & & & $\begin{array}{l}12 \pm 2 \\
n=7\end{array}$ & $\begin{array}{l}15 \pm 3 \\
n=7\end{array}$ & & $\begin{array}{l}8 \pm 1 \\
n=5\end{array}$ & $\begin{array}{l}7 \pm 2 \\
n=5\end{array}$ \\
\hline Cortex & 3 & $\begin{array}{l}20 \pm 6 \\
\mathrm{n}=8\end{array}$ & $\begin{array}{l}11 \pm 2 \\
n=8\end{array}$ & $\begin{array}{l}8 \pm 0.4 \\
n=4\end{array}$ & $\begin{array}{l}9 \pm 0.1 \\
n=4\end{array}$ & $\begin{array}{l}10 \pm 0.1 \\
\mathrm{n}=3\end{array}$ & & $\begin{array}{l}10 \pm 0.1 \\
\mathrm{n}=3\end{array}$ & $\begin{array}{l}9 \pm 0.6 \\
n=5\end{array}$ & & $\begin{array}{l}10 \pm 0.1 \\
n=5\end{array}$ \\
\hline Cortex & 6 & & & & & $\begin{array}{l}10 \pm 0.1 \\
\mathrm{n}=3\end{array}$ & & $\begin{array}{l}7 \pm 1 \\
n=3\end{array}$ & $\begin{array}{l}7 \pm 1.2 \\
n=5\end{array}$ & & $\begin{array}{l}8 \pm 1 \\
n=5\end{array}$ \\
\hline Hippocampus & 3 & $\begin{array}{l}14 \pm 4 \\
\mathrm{n}=4\end{array}$ & $\begin{array}{l}15 \pm 3 \\
\mathrm{n}=4\end{array}$ & $\begin{array}{l}8 \pm 1.1 \\
n=4\end{array}$ & $\begin{array}{l}9 \pm 0.3 \\
n=4\end{array}$ & $\begin{array}{l}7 \pm 2 \\
n=3\end{array}$ & & $\begin{array}{l}7 \pm 1 \\
n=3\end{array}$ & $\begin{array}{l}7 \pm 1 \\
n=5\end{array}$ & & $\begin{array}{l}9 \pm 1 \\
n=5\end{array}$ \\
\hline Hippocampus & 6 & $\begin{array}{l}6 \pm 1 \\
n=4\end{array}$ & $\begin{array}{l}6 \pm 2 \\
n=4\end{array}$ & $\begin{array}{l}9 \pm 0.05 \\
\mathrm{n}=4\end{array}$ & $\begin{array}{l}9 \pm 0.02 \\
\mathrm{n}=4\end{array}$ & $\begin{array}{l}5 \pm 2 \\
n=4\end{array}$ & $\begin{array}{l}8 \pm 2 \\
n=4\end{array}$ & & $\begin{array}{l}15 \pm 8 \\
n=6\end{array}$ & $\begin{array}{l}32 \pm 14 \\
\mathrm{n}=6\end{array}$ & \\
\hline Hippocampus & 6 & & & & & $\begin{array}{l}8 \pm 1 \\
n=3\end{array}$ & & $\begin{array}{l}8 \pm 2 \\
n=3\end{array}$ & $\begin{array}{l}7 \pm 1 \\
n=5\end{array}$ & & $\begin{array}{l}9 \pm 1 \\
n=5\end{array}$ \\
\hline
\end{tabular}

Values denote means \pm SD unless specified otherwise.

${ }^{*} \mathrm{p}<0.05$ when combined data includes both genders. Individual gender comparisons are not significant.

\section{Whole Brain Slices}

Control Animals. In the flow cytometric analysis of the slices, the positivity threshold for identifying nNOSpositive cells was set as the 95th percentile of the isotype controls (for the online supplementary figure, see www. karger.com/doi/10.1159/000327241). The threshold for NeuN-positive cells was also set based on the isotype controls (online suppl. fig.). From double staining of E29 fetal brain cells with nNOS (FITC) and NeuN (APC) antibodies, we found $62.5 \pm 11.5 \%$ of the cells were NeuN positive. nNOS-positive cells constituted $17.0 \pm 3.2 \%$ of the total number of cells (means $\pm \mathrm{SD} ; \mathrm{n}=3$ ), and $99.2 \pm$ $0.78 \%$ of the nNOS-positive cells were NeuN positive. Among the NeuN-positive cells, $27.5 \pm 4.9 \%$ were nNOS positive. Thus, most of the nNOS-positive cells were neurons. To determine whether JI-8 has any detrimental effects on neuronal cells, we studied brain slices obtained from non-HI control fetuses. Flow cytometric assessment of the whole brain slices at $72 \mathrm{~h}$ showed no difference in cell death (not shown) or mitochondrial function between the saline- and JI-8-treated groups (table 1). This shows that JI-8 does not exert any significant untoward effects on neuronal cells. Also, in the absence of increased nNOS expression, JI- 8 does not offer any significant benefit.

HI Animals. At $72 \mathrm{~h}$, flow cytometric assessment of the whole brain slices obtained after in utero HI showed that mitochondrial function was significantly better preserved in slices treated with JI-8 compared with saline (fig. 5). JC-1 staining of intact mitochondria is a spectrum ranging from green to red, the latter representing betterfunctioning mitochondria. In order to get a more accurate estimate of the number of cells with intact mitochondria, we evaluated both the total number of JC-1-stained cells and the number of cells staining more red than green. In this way, we accounted for all the cells with in- 
Fig. 5. Flow cytometric assessment of mitochondrial function at $72 \mathrm{~h}$ using JC-1 in whole brain slices from HI rabbit fetuses treated with the nNOS inhibitor JI-8 compared with saline. ${ }^{*} \mathrm{p}<0.05$. a Significant increase in total number of cells stained with JC-1 in the JI-8-treated group compared with saline. $\mathbf{b}$ Significant increase in number of cells staining more red than green with JC-1 in slices treated with JI-8 compared with saline.

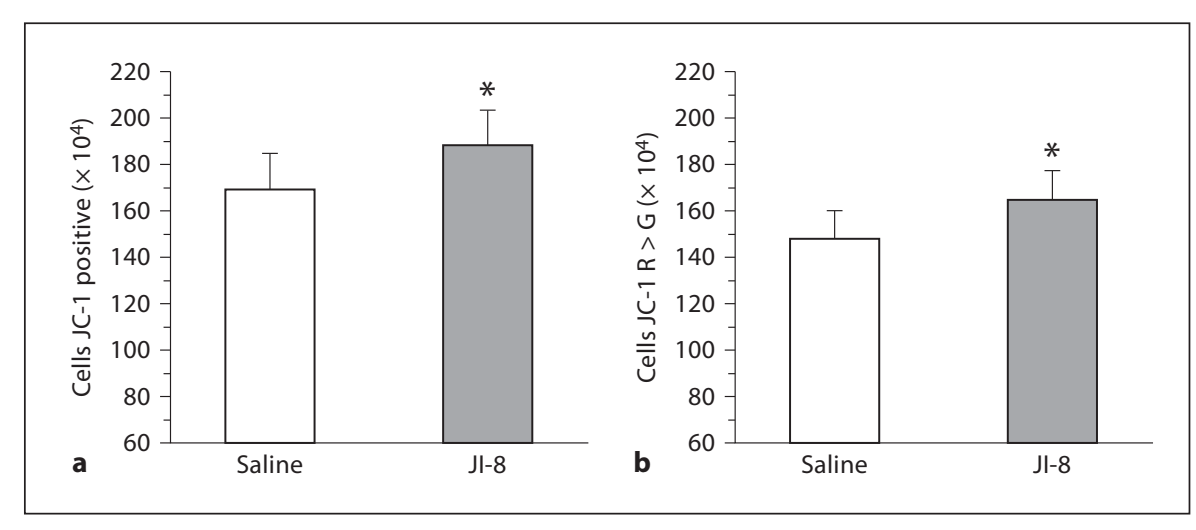

tact functioning mitochondria. By using paired control slices every time, we were able to set off any inconsistencies in staining with JC-1. To further corroborate our findings, we used rhodamine 123 to stain the mitochondria. This again showed significantly better-preserved mitochondria in the JI-8-treated group compared with saline. PI staining of dead cells was not significantly different between groups.

\section{Parietal Cortex and Hippocampus}

It is essential to understand any regional differences in vulnerability to HI injury to the brain. This may aid us in targeting specific areas to administer potential neuroprotective agents.

Control Animals. In the control animals, there was no difference in cell death or mitochondrial function between the JI-8-treated group and the saline group in both the parietal cortex and hippocampus.

HI Animals. In slices obtained after HI injury, at $144 \mathrm{~h}$, mitochondrial function was significantly better in the JI-8-treated group than in the saline group in both the parietal cortex and hippocampus (fig. 6). This is evidenced by the total number of JC-1-positive cells, of cells staining red more than green with JC-1, and of rhodamine 123-positive cells. Again there was no difference in PI-positive cells. There was no statistical difference between parietal cortex and hippocampus, both areas showing a similar number of intact mitochondria. This indicates that both the parietal cortex and hippocampus are vulnerable areas and could benefit from nNOS inhibition.

\section{Role of iNOS after HI Injury}

In order to address the question of the involvement of iNOS in ongoing NO production after HI injury, we used the selective iNOS inhibitor $1400 \mathrm{~W}$.
Control Animals. The flow cytometric assessment of the whole brain slices at $72 \mathrm{~h}$ in the control animals showed no statistical difference in cell death or mitochondrial function in parietal cortex or hippocampus between saline- and 1400W-treated groups (table 1,2).

HI Animals. Flow cytometry of slices obtained after $\mathrm{HI}$ also did not show any statistical difference in cell death or mitochondrial function between saline- and $1400 \mathrm{~W}$-treated groups at $72 \mathrm{~h}$. This indicates that iNOS is not a significant contributor to the ongoing NO pool in the brain after HI injury. Therefore, iNOS inhibition offers no significant benefit.

\section{JI-8 (nNOS Inhibitor) versus 1400W (iNOS Inhibitor)}

In order to minimize the effects of individual animal and slice variability, we compared JI- 8 directly with 1400W.

Control Animals. Flow cytometric assessment of the whole brain slices at 72 and $144 \mathrm{~h}$ in the control animals showed statistically significant preservation of mitochondrial function in the JI-8-treated group compared with the $1400 \mathrm{~W}$ group. There was no difference in PI between the two groups.

HI Animals. After HI, mitochondria were better preserved in the JI-8-treated group compared with the $1400 \mathrm{~W}$-treated group, as evidenced by rhodamine 123 staining (fig. 7). This indicates that nNOS inhibition is much more beneficial than iNOS inhibition.

\section{Gender Differences}

To determine whether gender plays a role in vulnerability to HI injury, we studied mitochondrial function in male and female fetuses (table 1,2). There was no statistically significant difference in cell death or mitochondrial function between male and female fetuses in the control or hypoxia groups treated with JI-8. 


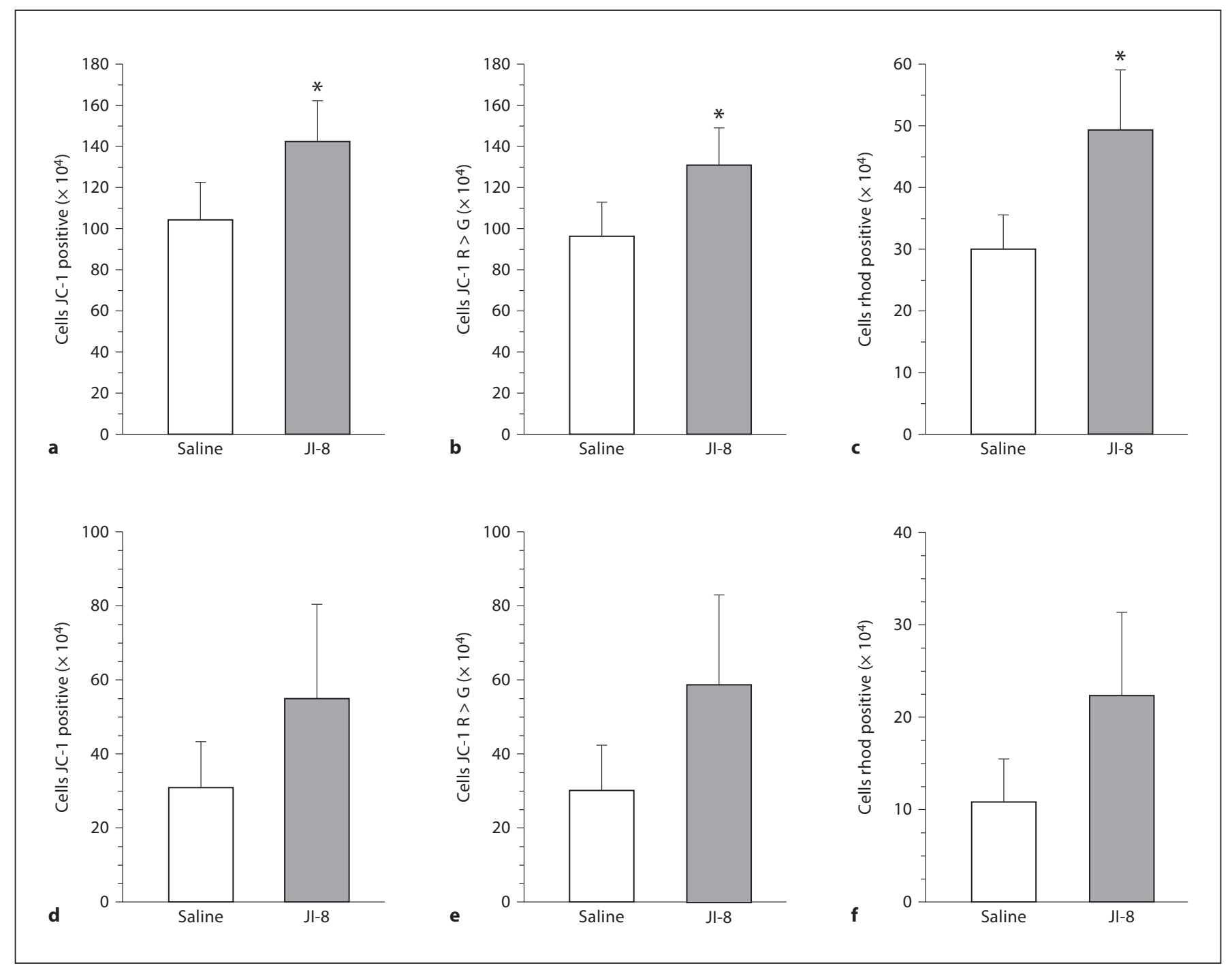

Fig. 6. Flow cytometric assessment of mitochondrial function at $144 \mathrm{~h}$ using JC-1 in slices of parietal cortex and hippocampus from HI rabbit fetuses treated with the nNOS inhibitor JI- 8 compared with saline. ${ }^{*} \mathrm{p}<0.05$. a Significant increase in the total number of cells in parietal cortical slices stained with JC-1 in the JI-8-treated group. b Significant increase in the number of cells staining more red than green with JC-1 in parietal cortical slices treated with JI-8. c Significant increase in the total number of rhodamine (rhod) 123-positive cells in cortical slices in the JI-8-treated group. d Significant increase in the total number of cells in hippocampal slices stained with JC-1 in the JI-8-treated group. e Significant increase in the number of cells staining more red than green with JC-1 in hippocampal slices treated with JI-8. f Significant increase in the total number of rhodamine (rhod) 123-positive cells in hippocampal slices in the JI-8-treated group.

\section{Discussion}

Perinatal HI injury to the brain is an important cause of long-term neurodevelopmental sequelae, especially in premature infants. The duration of injury extends far beyond the acute phase of HI. Our study has shown that NO plays a crucial role in the ongoing injury to neuronal cells for as long as 6 days after an HI event. The establishment of timing and mechanisms involved in HI injury is critical for planning management strategies aimed at preventing further brain damage. The subacute brain slices obtained from the rabbit model of global $\mathrm{HI}$ in utero that results in a cerebral palsy phenotype $[15,19,23,26]$ has allowed us to test various treatment strategies, especially 
Table 2. JC-1 flow cytometry assessment in control and hypoxia slices

\begin{tabular}{|c|c|c|c|c|c|c|c|c|c|c|c|}
\hline \multirow{3}{*}{$\begin{array}{l}\text { Cells JC-1 } \\
\mathrm{R}>\mathrm{G}+\mathrm{ve}\end{array}$} & \multirow{3}{*}{$\begin{array}{l}\text { Age } \\
\text { days }\end{array}$} & \multicolumn{4}{|c|}{ Control, fluorescence units } & \multicolumn{6}{|c|}{ Hypoxia, fluorescence units } \\
\hline & & \multicolumn{2}{|l|}{ nNOS } & \multicolumn{2}{|l|}{$\mathrm{iNOS}$} & \multicolumn{2}{|c|}{ nNOS } & \multicolumn{2}{|l|}{ iNOS } & \multirow{2}{*}{$\begin{array}{l}\text { nNOS } \\
\text { JI-8 } \\
\text { female }\end{array}$} & \multirow{2}{*}{$\begin{array}{l}\text { iNOS } \\
1400 \mathrm{~W} \\
\text { female }\end{array}$} \\
\hline & & saline & JI-8 & saline & $1400 \mathrm{~W}$ & $\begin{array}{l}\text { saline } \\
\text { male }\end{array}$ & $\begin{array}{l}\text { JI-8 } \\
\text { male }\end{array}$ & $\begin{array}{l}1400 \mathrm{~W} \\
\text { male }\end{array}$ & $\begin{array}{l}\text { saline } \\
\text { female }\end{array}$ & & \\
\hline Whole brain & 3 & $\begin{array}{l}168 \pm 8 \\
n=32\end{array}$ & $\begin{array}{l}177 \pm 9 \\
\mathrm{n}=32\end{array}$ & & & & & & & & \\
\hline Whole brain & 3 & & $\begin{array}{l}45 \pm 8 \\
\mathrm{n}=4\end{array}$ & & $\begin{array}{l}25 \pm 5^{*} \\
\mathrm{n}=4\end{array}$ & & & & & & \\
\hline Whole brain & 6 & & & & & & $\begin{array}{l}18 \pm 7 \\
n=7\end{array}$ & $\begin{array}{l}21 \pm 5 \\
n=7\end{array}$ & & $\begin{array}{l}20 \pm 7 \\
\mathrm{n}=5\end{array}$ & $\begin{array}{l}30 \pm 10 \\
\mathrm{n}=5\end{array}$ \\
\hline Cortex & 3 & $\begin{array}{l}82 \pm 12 \\
\mathrm{n}=8\end{array}$ & $\begin{array}{l}72 \pm 5 \\
\mathrm{n}=8\end{array}$ & $\begin{array}{l}8 \pm 0.1 \\
n=4\end{array}$ & $\begin{array}{l}8 \pm 0.1 \\
\mathrm{n}=4\end{array}$ & $\begin{array}{l}8 \pm 0.2 \\
\mathrm{n}=3\end{array}$ & & $\begin{array}{l}7 \pm 0.6 \\
\mathrm{n}=3\end{array}$ & $\begin{array}{l}8 \pm 0.2 \\
\mathrm{n}=5\end{array}$ & & $\begin{array}{l}8 \pm 0.2 \\
n=5\end{array}$ \\
\hline Cortex & 6 & $\begin{array}{l}73 \pm 8 \\
n=8\end{array}$ & $\begin{array}{l}63 \pm 7 \\
\mathrm{n}=8\end{array}$ & $\begin{array}{l}7 \pm 0.4 \\
\mathrm{n}=4\end{array}$ & $\begin{array}{l}8 \pm 0.3 \\
\mathrm{n}=4\end{array}$ & $\begin{array}{l}106 \pm 20 \\
n=4\end{array}$ & $\begin{array}{l}137 \pm 11 \\
\mathrm{n}=4\end{array}$ & & $\begin{array}{l}90 \pm 24 \\
\mathrm{n}=6\end{array}$ & $\begin{array}{l}126 \pm 30 \\
\mathrm{n}=6\end{array}$ & \\
\hline Cortex & 6 & & & & & $\begin{array}{l}7 \pm 0.4 \\
\mathrm{n}=3\end{array}$ & & $\begin{array}{l}7 \pm 0.2 \\
\mathrm{n}=3\end{array}$ & $\begin{array}{l}7 \pm 0.7 \\
\mathrm{n}=5\end{array}$ & & $\begin{array}{l}8 \pm 0.2 \\
\mathrm{n}=5\end{array}$ \\
\hline Hippocampus & 3 & $\begin{array}{l}58 \pm 13 \\
\mathrm{n}=4\end{array}$ & $\begin{array}{l}50 \pm 9 \\
\mathrm{n}=4\end{array}$ & $\begin{array}{l}7 \pm 0.2 \\
\mathrm{n}=4\end{array}$ & $\begin{array}{l}8 \pm 0.3 \\
n=4\end{array}$ & $\begin{array}{l}7 \pm 1 \\
\mathrm{n}=3\end{array}$ & & $\begin{array}{l}7 \pm 0.3 \\
\mathrm{n}=3\end{array}$ & $\begin{array}{l}7 \pm 0.5 \\
\mathrm{n}=5\end{array}$ & & $\begin{array}{l}8 \pm 0.7 \\
n=5\end{array}$ \\
\hline Hippocampus & 6 & $\begin{array}{l}45 \pm 4 \\
\mathrm{n}=4\end{array}$ & $\begin{array}{l}22 \pm 11 \\
\mathrm{n}=4\end{array}$ & $\begin{array}{l}6 \pm 0.3 \\
n=4\end{array}$ & $\begin{array}{l}6 \pm 0.5 \\
n=4\end{array}$ & $\begin{array}{l}16 \pm 6 \\
n=4\end{array}$ & $\begin{array}{l}22 \pm 9 \\
\mathrm{n}=4\end{array}$ & & $\begin{array}{l}39 \pm 20 \\
n=6\end{array}$ & $\begin{array}{l}84 \pm 37 \\
\mathrm{n}=6\end{array}$ & \\
\hline Hippocampus & 6 & & & & & $\begin{array}{l}7 \pm 0.8 \\
\mathrm{n}=3\end{array}$ & & $\begin{array}{l}6 \pm 1.5 \\
n=3\end{array}$ & $\begin{array}{l}6 \pm 0.8 \\
n=5\end{array}$ & & $\begin{array}{l}6 \pm 1.5 \\
n=5\end{array}$ \\
\hline
\end{tabular}

Values denote means \pm SD unless specified otherwise.

${ }^{*} \mathrm{p}<0.05$ vs. JI-8.

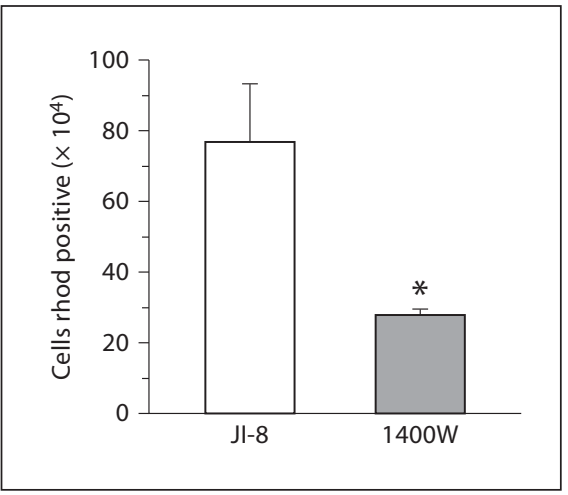

Fig. 7. Flow cytometric assessment of mitochondrial function at $72 \mathrm{~h}$ using rhodamine (rhod) 123 in whole brain slices from HI rabbit fetuses treated with the nNOS inhibitor JI-8 compared with the iNOS inhibitor $1400 \mathrm{~W}$. Significant increase in the number of rhodamine-positive cells in JI-8-treated slices compared with 1400W. ${ }^{*} \mathrm{p}<0.05$.
nNOS inhibitors in a clinically relevant animal model. This subacute brain slice model also brings to light the window of opportunity that is available to us to potentially administer nNOS inhibitors and thereby limit the extent of injury to the brain.

Prior studies in our laboratory have shown that nNOS inhibitors given to the dams prior to the HI event can result in amelioration of the motor deficits in the fetuses. All the mother-baby pairs who are likely to have HI events could potentially be treated with nNOS inhibitors to prevent $\mathrm{HI}$ injury, but clinically, it is extremely difficult to identify all such pairs. Even when the potential for $\mathrm{HI}$ is detected early, there may not be sufficient time to administer neuroprotective agents prior to the occurrence of the actual HI event. There are no specific postnatal interventions available that offer significant neuroprotection. This led us to investigate potential neuroprotective agents that can be given after the $\mathrm{HI}$ event has already occurred, much like in 
the clinical setting. The innovative method of obtaining brain slices after in utero HI has allowed us to analyze the ongoing cellular processes with particular emphasis on $\mathrm{NO}$ and nNOS. The viability of the slices over several days in culture shows that it is a valid model to study the effects of NO and nNOS inhibitors as potential treatment strategies. We used a novel designer chemical called JI- 8 that is a highly selective inhibitor of nNOS. It has a relative $\mathrm{K}_{\mathrm{i}}$ of 300 times for iNOS and 2,000 times for eNOS [27]. This ensured that only nNOS is inhibited. From our analysis of $\mathrm{NO}_{\mathrm{x}}$ from slices obtained from $\mathrm{HI}$ brains, we can infer that the expression of nNOS is increased after HI injury. This nNOS can be inhibited by JI- 8 and can thus significantly reduce the production of $\mathrm{NO}$ in the brain. This led us to pursue further studies with this drug.

The study of control animals using saline and JI-8 showed that there was no difference in cell death or mitochondrial function. This indicates that JI- 8 is not toxic to cells and does not cause increased cell death or injury to live cells at the concentration used. Our laboratory has previously shown that the process of preparing a singlecell suspension of the brain does not inflict new injury to cells [23]. The cells that are already dead or dying may possibly slough off during the process of preparing the brain cell suspension. This could possibly explain the lack of significant difference between the number of PI-positive cells in slices treated with saline or JI-8 both in control groups and hypoxia groups. We therefore concentrated our analysis on mitochondrial membrane potential and function using JC-1 and rhodamine 123.

Intact mitochondria are crucial for intact cell survival and function. In the whole brain slices obtained after HI, the mitochondrial membrane potential and function were significantly better when treated with the nNOS inhibitor JI-8. This again indicates that nNOS expression is increased after HI. The increased expression of nNOS after HI, as shown by prior preliminary RT-PCR studies in our laboratory, further corroborates our current findings. Short-term inhibition of nNOS after an HI event protects the cells from the deleterious effects of NO. By using JC-1, we were able to partially quantify the number of healthy cells with intact mitochondria. Using paired matched controls enabled us to set off any individual staining differences by JC-1. Mitochondrial integrity was further corroborated by using rhodamine 123 staining.

Determining specific vulnerable areas in the brain could play a key role in developing potential neuroprotective agents. In our study, the slices from the parietal cortex and hippocampus after HI showed significant protection of mitochondria in the JI-8-treated group, suggest- ing that $\mathrm{nNOS}$ and $\mathrm{NO}$ are expressed in amounts that are likely to cause significant damage to cells in these areas. Selective nNOS inhibition in the parietal cortex and hippocampus offers neuroprotection in the subacute phase of HI injury for as long as 6 days after the HI event. Comparison of parietal cortex with hippocampus did not show a significant difference in terms of mitochondrial protection offered by JI-8, which leads us to believe that both regions are extremely vulnerable to $\mathrm{HI}$ injury. Residual injury in these areas is likely to lead to neurodevelopmental delays in the long run. These are the areas that need to be targeted by neuroprotective agents.

Another factor that could potentially affect NO production in the brain is iNOS. Our study shows that iNOS does not contribute significantly to the ongoing $\mathrm{NO}$ pool in the brain after $\mathrm{HI}$ injury. Most of the NO is produced by nNOS. After suffering in utero HI injury, iNOS inhibition with $1400 \mathrm{~W}$ offers no significant benefit in terms of mitochondrial protection compared with nNOS inhibition by JI-8.

Our study also evaluated the possible effect of gender differences in the vulnerability to HI injury between males and females. Gender determination of the rabbit fetuses was done by PCR. Our study did not show any significant difference in terms of cell death or mitochondrial function between males and females both in control groups and hypoxia groups treated with JI- 8 or saline. It is possible that our study was underpowered to establish a statistical significance between the two sexes.

In summary, our innovative brain slice model offers the opportunity to analyze the various cellular mechanisms involved in ongoing $\mathrm{HI}$ injury to the brain in the subacute phase. It also provides a quick and easy model for studying the effects of several potential neuroprotectants. NO produced from nNOS is an important mediator of ongoing mitochondrial dysfunction in neuronal cells, not only in the acute phase but also in the subacute phase of HI injury. Inhibition with the highly selective nNOS inhibitor JI-8 offers significant neuroprotection up to 6 days after the in utero HI insult. This could have potentially useful and clinically important therapeutic benefits.

\section{Acknowledgment}

This research was supported by grants from the NIH (NS 043285; to S.T.). 


\section{References}

1 Volpe JJ: Neurology of the Newborn, ed 4. 11 Park JH, Straub VA, O’Shea M: Anterograde Philadelphia, WB Saunders, 2001.

2 Vannucci RC: Hypoxic-ischemic encephalopathy. Am J Perinatol 2000;17:113-120.

$\checkmark 3$ MacDonald HM, Mulligan JC, Allen AC, Taylor PM: Neonatal asphyxia. 1. Relationship of obstetric and neonatal complications to neonatal mortality in 38,405 consecutive deliveries. J Pediatr 1980;96:898-902.

4 O'Shea TM: Cerebral palsy in very preterm infants: new epidemiological insights. Ment Retard Dev Disabil Res Rev 2002;8:135-145.

5 Ancel PY, Livinec F, Larroque B, Marret S, Arnaud C, Pierrat V, Dehan M, N'Guyen S, Escande B, Burguet A, Thiriez G, Picaud JC, André M, Bréart G, Kaminski M: Cerebral palsy among very preterm children in relation to gestational age and neonatal ultrasound abnormalities: the EPIPAGE cohort study. Pediatrics 2006;117:828-835.

-6 Gluckman PD, Wyatt JS, Azzopardi D, Ballard R, Edwards AD, Ferriero DM, Polin RA, Robertson CM, Thoresen M, Whitelaw A, Gunn AJ: Selective head cooling with mild systemic hypothermia after neonatal encephalopathy: multicentre randomised trial. Lancet 2005;365:663-670.

7 Shankaran S, Laptook AR, Ehrenkranz RA, Tyson JE, McDonald SA, Donovan EF, Fanaroff AA, Poole WK, Wright LL, Higgins RD, Finer NN, Carlo WA, Duara S, Oh W, Cotten CM, Stevenson DK, Stoll BJ, Lemons JA, Guillet R, Jobe AH: Whole-body hypothermia for neonates with hypoxic-ischemic encephalopathy. N Engl J Med 2005;353: 1574-1584.

8 Perlman JM: Intervention strategies for neonatal hypoxic-ischemic cerebral injury. Clin Ther 2006;28:1353-1365.

9 Taeusch HW, Ballard RA, Gleason CA, Avery ME: Avery's Diseases of the Newborn. Philadelphia, Elsevier Saunders, 2005, pp 965-992.

10 Hölscher C: Nitric oxide, the enigmatic neuronal messenger: its role in synaptic plasticity. Trends Neurosci 1997;20:298-303. signaling by nitric oxide: characterization and in vitro reconstitution of an identified nitrergic synapse. J Neurosci 1998;18:54635476.

12 Bredt DS, Snyder SH: Nitric oxide, a novel neuronal messenger. Neuron 1992;8:3-11.

13 Calabrese V, Mancuso C, Calvani M, Rizzarelli E, Butterfield DA, Stella AM: Nitric oxide in the central nervous system: neuroprotection versus neurotoxicity. Nat Rev Neurosci 2007;8:766-775.

14 Dawson VL, Dawson TM, Bartley DA, Uhl GR, Snyder SH: Mechanisms of nitric oxidemediated neurotoxicity in primary brain cultures. J Neurosci 1993;13:2651-2661.

15 Derrick M, Luo NL, Bregman JC, Jilling T, Ji X, Fisher K, Gladson CL, Beardsley DJ, Murdoch G, Back SA, Tan S: Preterm fetal hypoxia-ischemia causes hypertonia and motor deficits in the neonatal rabbit: a model for human cerebral palsy? J Neurosci 2004;24: 24-34.

16 Eliasson MJ, Huang Z, Ferrante RJ, Sasamata M, Molliver ME, Snyder SH, Moskowitz MA: Neuronal nitric oxide synthase activation and peroxynitrite formation in ischemic stroke linked to neural damage. J Neurosci 1999;19:5910-5918.

17 Vincent SR, Kimura H: Histochemical mapping of nitric oxide synthase in the rat brain. Neuroscience 1992;46:755-784.

18 Tan S, Zhou F, Nielsen VG, Wang Z, Gladson CL, Parks DA: Sustained hypoxia-ischemia results in reactive nitrogen and oxygen species production and injury in the premature fetal rabbit brain. J Neuropathol Exp Neurol 1998;57:544-553.

19 Tan S, Zhou F, Nielsen VG, Wang Z, Gladson CL, Parks DA: Increased injury following intermittent fetal hypoxia-reoxygenation is associated with increased free radical production in fetal rabbit brain. J Neuropathol Exp Neurol 1999;58:972-981.

20 Ayata C, Ayata G, Hara H, Matthews RT, Beal MF, Ferrante RJ, Endres M, Kim A, Christie RH, Waeber C, Huang PL, Hyman BT, Moskowitz MA: Mechanisms of reduced striatal NMDA excitotoxicity in type I nitric oxide synthase knock-out mice. J Neurosci 1997;17:6908-6917.
21 Dalkara T, Yoshida T, Irikura K, Moskowitz MA: Dual role of nitric oxide in focal cerebral ischemia. Neuropharmacology 1994;33: 1447-1452.

22 Ferriero DM, Holtzman DM, Black SM, Sheldon RA: Neonatal mice lacking neuronal nitric oxide synthase are less vulnerable to hypoxic-ischemic injury. Neurobiol Dis 1996;3: 64-71.

23 Derrick M, He J, Brady E, Tan S: The in vitro fate of rabbit fetal brain cells after acute in vivo hypoxia. J Neurosci 2001;21:RC138.

$24 \mathrm{Ji} \mathrm{H}$, Stanton BZ, Igarashi J, Li H, Martasek P, Roman LJ, Poulos TL, Silverman RB: Minimal pharmacophoric elements and fragment hopping, an approach directed at molecular diversity and isozyme selectivity: design of selective neuronal nitric oxide synthase inhibitors. J Am Chem Soc 2008; 130:3900-3914.

25 Ji H, Tan S, Igarashi J, Li H, Derrick M, Martasek P, Roman LJ, Vasquez-Vivar J, Poulos TL, Silverman RB: Selective neuronal nitric oxide synthase inhibitors and the prevention of cerebral palsy. Ann Neurol 2009;65:209217.

26 Derrick M, Drobyshevsky A, Ji X, Chen L, Yang Y, Ji H, Silverman RB, Tan S: Hypoxiaischemia causes persistent movement deficits in a perinatal rabbit model of cerebral palsy: assessed by a new swim test. Int J Dev Neurosci 2009;27:549-557.

27 Ji H, Li H, Martasek P, Roman LJ, Poulos TL, Silverman RB: Discovery of highly potent and selective inhibitors of neuronal nitric oxide synthase by fragment hopping. J Med Chem 2009;52:779-797.

-28 Drobyshevsky A, Derrick M, Prasad PV, Ji X, Englof I, Tan S: Fetal brain magnetic resonance imaging response acutely to hypoxiaischemia predicts postnatal outcome. Ann Neurol 2007;61:307-314.

29 Jaroszeski MJ, Radcliff G: Fundamentals of flow cytometry. Mol Biotechnol 1999;11:3753. 